\title{
Spending Today or Saving for Tomorrow: The Influence of Family Financial Socialization on Financial Preparation for Retirement
}

\author{
Scott H. Payne \\ Brigham Young University - Provo \\ Jeremy B. Yorgason \\ Brigham Young University - Provo \\ Jeffrey P. Dew \\ Brigham Young University - Provo, jeff_dew@byu.edu
}

Follow this and additional works at: https://scholarsarchive.byu.edu/facpub

Part of the Other Social and Behavioral Sciences Commons

\section{Original Publication Citation}

Payne, S.*, Yorgason, J., \& Dew, J. P. (2014). Spending today or saving for tomorrow: The influence of family financial socialization on financial preparation for retirement. Journal of Family and Economic Issues, 35, $106-118$.

\section{BYU ScholarsArchive Citation}

Payne, Scott H.; Yorgason, Jeremy B.; and Dew, Jeffrey P., "Spending Today or Saving for Tomorrow: The Influence of Family Financial Socialization on Financial Preparation for Retirement" (2013). Faculty Publications. 4531.

https://scholarsarchive.byu.edu/facpub/4531

This Peer-Reviewed Article is brought to you for free and open access by BYU ScholarsArchive. It has been accepted for inclusion in Faculty Publications by an authorized administrator of BYU ScholarsArchive. For more information, please contact ellen_amatangelo@byu.edu. 


\title{
Spending Today or Saving for Tomorrow: The Influence of Family Financial Socialization on Financial Preparation for Retirement
}

\author{
Scott H. Payne $\cdot$ Jeremy B. Yorgason • \\ Jeffrey P. Dew
}

Published online: 27 June 2013

(c) Springer Science+Business Media New York 2013

\begin{abstract}
Many of the factors that motivate individuals occur within the context of the family, and can be influenced through family socialization processes. To better understand the influence family socialization processes may have on financial capabilities and financial behaviors, 334 married couples were sampled. Structural equation modeling was used to examine both direct and indirect associations. Findings indicated direct relationships between materialism and financial strain, between religiosity and determination of needs, and between financial strain and saving for retirement. Indirect relationships were found between materialism and saving for retirement through financial strain. Our study found evidence to support the Family Financial Socialization theoretical framework. Financial counselors may benefit by understanding how couples socialize each other as they prepare for retirement.
\end{abstract}

Keywords Family socialization - Financial strain · Materialism · Religiosity $\cdot$ Retirement preparation

\footnotetext{
S. H. Payne $(\bowtie)$

Marriage, Family, Human Development, 307 HCEB,

Brigham Young University, Provo, UT 84602, USA

e-mail: scott.payne@byu.edu
}

J. B. Yorgason

School of Family Life, 2079 JFSB, Brigham Young University, Provo, UT 84602, USA

e-mail: jeremy_yorgason@byu.edu

J. P. Dew

Department of Family, Consumer, and Human Development, Utah State University, 670 E. 500 N., Logan, UT 84321, USA

e-mail: jeff.dew@usu.edu

\section{Introduction}

As the responsibility for funding one's retirement continues to shift back to the individual (Federal Interagency Forum on Aging-Related Statistics 2008), it is becoming increasingly important to understand what may motivate individuals to prepare for retirement. One example of this shift can be seen in the Employee Benefit Research Institute's (2010) databook, suggesting that $71 \%$ of the private-sector retirement plans were self-funded in 1978. This number grew to $93 \%$ in 2006 which represents an increase of 22 percentage points. This change, coupled with increased longevity, has created a challenge not seen in recent retiring generations. To meet this challenge, individuals and couples need to plan better and prepare more so that they will have enough funds available during retirement to meet their expected standard of living. Not planning adequately for one's financial needs in retirement can lead to various incurred risks, including not being able to stop working when desired or when health limitations occur, having to take on debt in retirement to pay expenses, financial strain, and potentially unfulfilled expectations of retirement plans.

Unfortunately, research has shown that many are not fully prepared to provide for their own retirement. For example, the share of income from assets for households 65 and over has decreased since the mid-1980s, and in 2006 accounted for just $15 \%$ of the total income for these households (Federal Interagency Forum on aging-Related Statistics 2008; Poterba et al. 2007). Additionally, between 1984 and 2007 personal savings rates, as a percentage of disposable income, declined from 10.2 to $2.1 \%$ with a rebound occurring during the recession to $5.8 \%$ in 2010 (Employee Benefit Research Institute 2011). Directly related to retirement saving, $68 \%$ of those participating in 
self-funded retirement plans in one study felt their savings rate was "too low" for their expected retirement spending (Choi et al. 2002). Further, as the landscape continues to transform from one of defined-benefit plans to one of defined-contribution plans (and as individuals save less), it becomes increasingly important to understand motivations behind preparation for retirement.

\section{Family Financial Socialization: A Contextual Framework}

Financial socialization theory provides a broad lens through which to consider preparation for retirement. Specifically, this theory addresses the development of financial "values, attitudes, standards, norms, knowledge, and behaviors that contribute to the financial viability and well-being" of individuals (Danes 1994, p. 128). Gudmunson and Danes (2011) proposed a model of family financial socialization which links family characteristics and interactions with financial socialization outcomes including behaviors, and well-being, through financial attitudes, knowledge, and capabilities. We adapt this model to provide a framework for the current study (Fig. 1). In the context of family relationships, people are socialized in how and when to spend and save, as well as how to prioritize spending and saving. According to Gudmunson and Danes (2011), some financial socialization occurs within families explicitly, yet most teaching and learning of financial behaviors occurs as family members observe the behavior of others. Such socialization is associated with the development of financial management capabilities, which they define in terms of financial attitudes, knowledge, and capabilities. In the current study, financial management capabilities are examined through respondents' sense of financial strain. Ultimately, family socialization and financial capabilities are linked with financial behaviors as outcomes, which might include "earning, saving, spending, and.... decision making" (Gudmunson and Danes 2011, p. 650).

Gudmunson and Danes (2011) noted that research has "discounted" the influence family relationships have on financial matters, such as retirement preparedness. Although financial socialization literature has examined ways that young people learn from their parents, fewer studies have considered ways that socialization may occur within marriage. The marital relationship can have a far reaching impact in couple's financial experiences. Skogrand et al. (2011) noted key financial management practices among couples identified as great marriages that included minimization of debt and living within their means. In addition, when couples' spending habits are in sync, marital conflict is reduced (Rick et al. 2010). Stafford et al. (1996) found that U.S. couples tend to share in the decision making process related to financial matters. Research has demonstrated the impact the marital relationship can have on financial matters, yet it is important to validate the martial influence on how couples prepare for and save for retirement (Noone et al. 2010).

Historically, various factors have been found to influence determining needs for and saving for retirement. Studies have investigated demographic, financial, and attitudinal predictors of retirement preparation and saving (Glass and Kilpatrick 1998; Hershey et al. 2007; Li et al. 1996; Petkoska and Earl 2009). Few, however, have examined links between attitudes learned during family socialization processes and retirement saving behaviors (see Hershey et al. 2010). Huhmann and McQuitty (2009) defined the family socialization process of materialism as "the importance that a consumer places on acquiring possessions and using possessions to achieve happiness or communicate status or success to others" (p. 282). More specifically, materialistic attitudes, which are known to motivate consumption (Belk 1985; Wilska 2002) and therefore may reduce the available resources for savings and investments (Watson 2003), may have a negative association with determining needs for and saving for retirement. Similarly, an attitude of religious observance (another socialization process that occurs within families), which may increase one's focus on thrift and savings rates (Guiso et al. 2003; Klaubert 2010), may be positively related to determining need for and saving for retirement. Last, financial strain has been linked negatively with saving (Hayhoe et al. 2000). Although materialism and religiosity have been associated with behaviors that facilitate general savings, the current study is aimed at exploring how these socialized attitudes relate to preparation and saving that is specific to retirement.

In addition, preparation for retirement often occurs within a marital context. As a form of socialization, spouses influence each other's timing of and planning for retirement (Ekerdt et al. 2000; Mock and Cornelius 2007; Moen et al. 2006; Moen et al. 2001). Examining retirement information from both husbands and wives contributes to a growing body of literature that is slowly incorporating more information about women in retirement (Kim and Moen 2002). Financial well-being has implications for marital relationships in retirement, such that having less debt and greater assets may act as buffers to financial strain for married couples in the retirement years (Dew and Yorgason 2010). In contrast, materialism has been found to have negative implications for marital relationships (Dean et al. 2007). In the current study, we examine financial behaviors associated with preparation for and saving for retirement within a marriage socialization context (Gudmunson and Danes 2011). Specifically, using data from 334 
Fig. 1 Family financial socialization theory in context of retirement preparation. Bottom panel: solid lines indicate actor paths. Dotted lines indicate partner paths
Top Panel: Modified Associations from Gudmunson and Danes (2011)

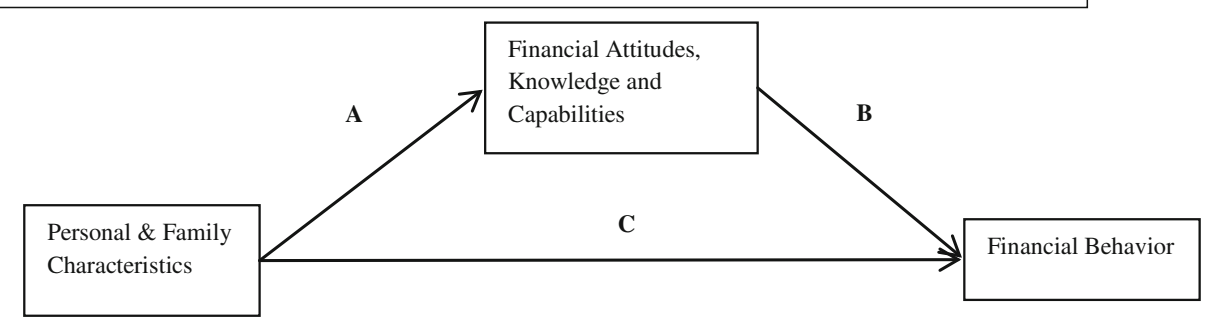

Bottom Panel: Application of the current study variables

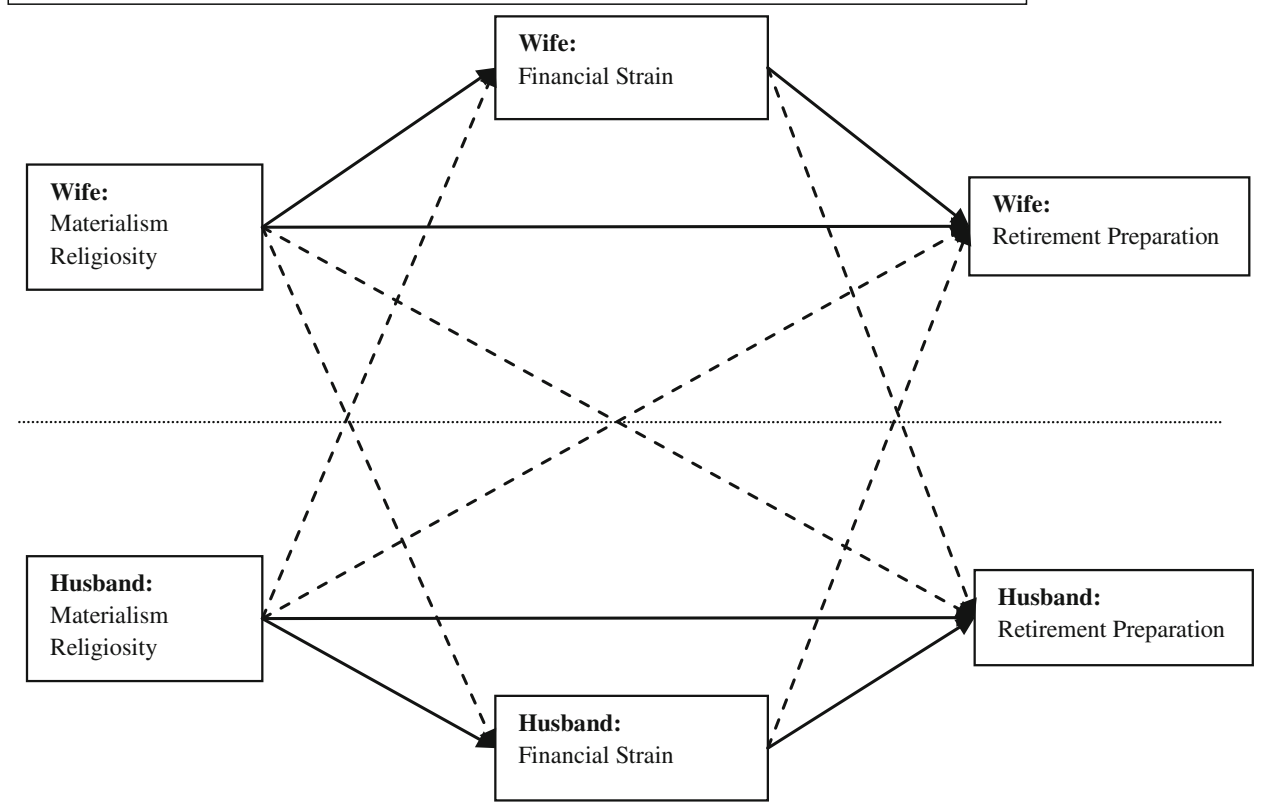

Various demographic and psychological predictors of preparing for and saving for retirement have been identified by researchers. Higher income, older age, higher education, and male gender have consistently been found to be the strongest predictors of financial preparation for retirement (Glass and Kilpatrick 1998; Hershey and Jacobs-Lawson 2012; Li et al. 1996; Topa et al. 2012). Although variability in these factors relates to financial preparation for retirement, individuals often are unable to change these characteristics. Key attitudinal factors in retirement preparation and saving, which may be more easily modified, include having a future orientation (Hershey et al. 2007; JacobsLawson and Hershey 2005), being goal oriented (Petkoska and Earl 2009), having a general orientation toward financial preparation (Hershey and Mowen 2000; Stawski et al. 2007), and having a higher financial risk tolerance or lower fear (Jacobs-Lawson and Hershey 2005; Neukam and Hershey 2003). These attitudinal variables generally appear to fit in Gudmunson and Danes (2011) theory under financial attitudes, knowledge, and capabilities and are part of financial socialization. What seem to be missing in the 
current literature are variables that are associated with family socialization processes.

Materialistic and Religious Attitudes as Family

Socialization Predictors

Two aspects of life that are often developed within families include materialism and religious observance. Beutler (2012) noted that families play an important role in the development of materialistic attitudes. In addition, Flouri (1999) found that interpersonal relationships, such as the family, impact materialistic values. While materialistic attitudes have been found to be socialized within the family environment, the question still remains as to whether or not they will influence preparing for and saving for retirement. Belk (1985) found that a materialistic attitude was linked with placing a higher importance on consuming rather than saving in order to obtain possessions. In a related study on attitudes somewhat similar to materialism, Samwick (2006) noted that those denoted as "impatient" households were more likely to focus on short-term consumption rather than on long-term sustainability, resulting in their starting retirement savings later in life. The tendency to spend in the moment has been linked to saving less for future needs (Troisi et al. 2006), financial overextension (Huhmann and McQuitty 2009), higher spending and borrowing patterns (Watson 2003), and higher levels of perceived financial problems (Dean et al. 2007). In essence, a desire to consume appears to have context within the family and be generally associated with financial behaviors that are often negatively correlated with saving.

Like materialism, religious attitudes are generally developed within the family context (Rymarz and Graham 2006). Mason et al. (2007) noted the strong influence that parents with higher religiosity had on their children's religious observance. Less is known about how religious attitudes may be associated with preparing for and saving for retirement. Religious attitudes and behaviors have generally been positively associated with various monetary outcomes, and lower risk-taking behaviors. First, using data from the National Longitudinal Survey of Youth 1979 cohort, Keister (2003) found that both religious affiliation and attendance were positively associated with various measures of wealth. In addition, in a study of 246 college students, Flouri (1999) found those with increased levels of religiosity held a less materialistic view. These studies provide support for the idea that religious individuals may have an increased attitude of thrift (Guiso et al. 2003), and suggest that in some ways religious values and attitudes are reflected in financial beliefs and behaviors (Komhauser 1994).
Influence of Financial Strain

Financial strain is often modeled as a mediating factor between objective financial predictors and various biopsychosocial outcomes. For example, financial strain has been found to have a mediating effect between income and depression (Schulz et al. 2006). In addition, it has mediated effects of income and employment on mothers' marital happiness and mother-child relationships (Lempers and Clark-Lempers 1997), as well as on overall life satisfaction (Xiao et al. 2009). This is in line with Gudmunson and Danes (2011) who identified financial attitudes as an "intermediary financial socialization outcome" (p. 649).

Financial strain has also been shown to have relationships with both materialistic and religious attitudes. Dean et al. (2007) noted the mediating effect of financial problems between higher materialism and lower marital satisfaction. Additionally, Walker (1996) found a significant relationship to exist between better financial management (which included savings), lower materialistic attitudes, and lower financial strain. Religious observance may encourage charitable giving (Burgoyne et al. 2005), even during times of financial hardship (Marks et al. 2009). These studies indicate the correlated nature between materialism, religious attitudes, and financial strain, and provide support for examining these links within a family socialization approach.

Hypotheses

Based on the family socialization theory, as well as research literature, we examine predictors of calculating expected retirement income needs and ownership of individual retirement savings. These outcomes are considered in the context of marriage, considering views from both husbands and wives. Family socialization predictors include materialism and religiosity. Financial capability, measured by financial strain, is viewed as a mediator between family processes and financial behaviors. We specifically hypothesized the following:

1. We hypothesized that family socialization (i.e., materialism and religiosity) would be linked with financial capability (i.e., financial strain; path $\mathrm{A}$ in Fig. 1), and with financial behavior (i.e., retirement preparation variables; path $\mathrm{C}$ in Fig. 1). Congruent with prior literature, we anticipated that materialism and religiosity would respectively be linked with financial strain in positive and negative directions, and with retirement preparation variables in exactly the opposite directions. We also hypothesized that decreased financial capability (i.e., financial strain) would be related to lower reports of certain financial behaviors (i.e., retirement preparation variables; Path B in Fig. 1). 
2. In addition to the direct associations mentioned above, we hypothesized that the links between materialism and the retirement preparation variables and between religiosity and the retirement preparation variables would operate indirectly through financial strain. As indicated in the family financial socialization theory, financial attitudes, knowledge, and capacities are theorized to mediate between family socialization processes and financial behaviors.

3. We offer competing hypotheses regarding how husband and wife reports relate to links between family socialization processes, financial capabilities, and financial behaviors. Some literature suggests disparate perceptions and experiences for husbands compared to wives (Glass and Kilpatrick 1998; Noone et al. 2010; Perkins 1995). In contrast, family socialization processes in marriage may influence these associations so that links between variables in the study are similar for husbands and wives. Due to these competing hypotheses, this question is exploratory.

\section{Method}

Sample

The participants for this study were taken from Wave 1 of the Flourishing Families Project (FFP). The FFP is a study of family life involving families with a child between the ages of 10 and 14. Most participant families were randomly selected from targeted census tracts in a large northwestern city using a national telephone database and were administered questionnaires in their homes. The overall response rate of eligible families was $61 \%$. To more closely mirror the demographics of the local area, a limited number of families were also recruited through other means (e.g., referrals, fliers; $N=77,15 \%$; for more information on participants and procedures, please see Padilla-Walker et al. 2010). The study consisted of 500 families, where parents and the target child completed a one and a half hour self-administered questionnaire, and certain interaction tasks were video recorded. In the current analysis we used data from the married couples' surveys in the study $(N=334)$. All of the couples had responses from both the husband and wife.

Due to the targeted age range of children in the FFP sample (i.e., families with at least one child between the ages of 10 and 14), spouses were within a fairly uniform stage of the marital lifespan (wives: $M$ age $=43.44, \mathrm{SD}=5.54$; husbands: $M$ age $=45.32$, SD $=6.23$ ). The average length of marriage was 17 years $(\mathrm{SD}=5.25)$, and on average both husbands and wives reported high marital quality levels (wives: $M$ marital quality $=5.15, \mathrm{SD}=0.97$, range of $1-6$; husbands: $M=5.18, \mathrm{SD}=0.91$, range of 1-6). Eighty-five percent of the participants for the current analysis were European American, $5 \%$ were African American, $3 \%$ were Asian American, $2 \%$ were Hispanic, and $5 \%$ indicated that they were "mixed/biracial" or of another ethnicity. The average family income per month was $\$ 7,035$ $(\mathrm{SD}=\$ 5,356)$, while the median family income was $\$ 6,038$.

\section{Measures}

Retirement preparation variables were measured by asking respondents the following: (1) Have you tried to figure out how much your household would need to save for retirement? (2) Do you have any private retirement funds set aside? Responses for these variables were "yes" (coded as 1) and "no" (coded as 0).

Materialism was measured with six items that assessed the degree to which participants held attitudes and values regarding spending and having new and expensive products. These items were taken from the Comprehensive Marriage Preparation Assessment Survey (Carroll 2004). Items included the following: (1) I like to have the newest products as soon as they come out, (2) Having a nice car is important to me, (3) Having a home or condo in a nice neighborhood is a priority for me, (4) I want my kids to dress in fashionable clothes, (5) I want my family to have the finer things in life, and (6) Having a high salary is an essential part of the lifestyle I want to live. Responses ranged on a scale of zero to four, with higher scores reflecting a more materialistic attitude. Reports from all six items were used to create a latent variable of materialism for husbands and a separate latent variable of materialism for wives. Factor loadings were all 0.49 or above (Table 1).

Financial capability was measured with five items that assessed the degree of financial strain an individual was under. Items included the following: (1) Difficulty meeting monthly payments on bills, (2) Having enough money at the end of the month after bills are paid, (3) Not enough money for housing, (4) Debt problems-concerns about owing money, and (5) Not enough money for health care. Responses ranged on a scale of $0-5$ with higher scores representing greater levels of financial strain. Reports from all five items were used to create a latent variable of financial strain for husbands and a separate latent variable of financial strain for wives. All factor loadings were above 0.80 .

Religiosity was measured with four items taken from the Santa Clara Strength of Religious Faith questionnaire (Lewis et al. 2001) that assessed the influence of faith in an individual's life. Items included the following: (1) I pray daily, (2) I look to my faith as providing meaning and purpose in 
Table 1 Latent variable measurement properties from measurement model

\begin{tabular}{|c|c|c|}
\hline \multirow[t]{2}{*}{ Constructs and contents } & \multicolumn{2}{|c|}{ Factor loadings } \\
\hline & Husband & Wife \\
\hline \multicolumn{3}{|l|}{ Materialism } \\
\hline $\begin{array}{l}\text { I like to have the newest products as soon as they } \\
\text { come out }\end{array}$ & 0.54 & 0.50 \\
\hline Having a nice car is important to me & 0.64 & 0.56 \\
\hline $\begin{array}{l}\text { Having a home or condo in a nice neighborhood } \\
\text { is a priority for me }\end{array}$ & 0.49 & 0.52 \\
\hline I want my kids to dress in fashionable clothes & 0.68 & 0.85 \\
\hline I want my family to have the finer things in life & 0.80 & 0.81 \\
\hline $\begin{array}{l}\text { Having a high salary is an essential part of the } \\
\text { lifestyle I want to live }\end{array}$ & 0.71 & 0.78 \\
\hline \multicolumn{3}{|l|}{ Religiosity } \\
\hline I pray daily & 0.89 & 0.90 \\
\hline $\begin{array}{l}\text { I look to my faith as providing meaning and } \\
\text { purpose in my life }\end{array}$ & 0.98 & 0.99 \\
\hline $\begin{array}{l}\text { My faith is an important part of who I am as a } \\
\text { person }\end{array}$ & 0.97 & 0.95 \\
\hline My faith impacts many of my decisions & 0.95 & 0.97 \\
\hline \multicolumn{3}{|l|}{ Financial strain } \\
\hline Difficulty meeting monthly payments on bills & 0.92 & 0.89 \\
\hline $\begin{array}{l}\text { Having enough money at the end of the month } \\
\text { after bills are paid }\end{array}$ & 0.82 & 0.82 \\
\hline Not enough money for housing & 0.88 & 0.82 \\
\hline Debt problems-concerns about owing money & 0.84 & 0.91 \\
\hline Not enough money for health care & 0.80 & 0.84 \\
\hline
\end{tabular}

my life, (3) My faith is an important part of who I am as a person, and (4) My faith impacts many of my decisions. Responses ranged on a scale of zero to three with higher scores reflecting higher levels of religious attitudes. All four items were used to create a latent variable of religiosity for husbands, and a separate latent variable of religiosity for wives. Factor loadings were all above 0.89 .

A number of demographic variables were measured including income, age, and education. The sample had an equal number of males and females at 334 . Income earned by adults in the household in a given month was used as family monthly income $(M=\$ 7,035, \quad \mathrm{SD}=\$ 5,356$, median $=\$ 6,038)$. Eleven families in the sample reported to earn more than two standard deviations above the mean (i.e., $\$ 17,800 /$ month). When these were removed from the sample, the average income per month was $\$ 6,323(\mathrm{SD}=\$ 2,731)$, while the median family income was $\$ 6,000$. In all analyses, the income measure was divided by 1,000 so that the scale was similar to other variables in the model. Age was given in whole years (females $M=43.44, \mathrm{SD}=5.36$; males $M=45.32$, $\mathrm{SD}=5.96$ ). Education is measured as a scale variable with responses ranging from one to seven, where one was less than a high school degree and seven was an advanced degree above a master's degree. Thirty-one and five tenths percent of the females had an associate's degree or lower degree. Forty and one tenth percent had a bachelor's degree, and the remaining $28.5 \%$ completed a master's or higher degree. Twenty-nine and four tenths percent of the males had an associate's degree or lower. Thirty-nine and six tenths percent had a bachelor's degree and the remaining $31 \%$ completed a master's or higher degree.

\section{Analysis of Data and Results}

Structural equation modeling with Mplus (Muthén and Muthén 2007) was used to assess links between husband and wife reports of latent constructs measuring materialism, financial strain, religiosity, and the two dichotomous outcomes of retirement preparation. Although materialism, financial strain, and religiosity items had response options across Likert-type scales, responses were not normally distributed across response options. As such, these items were modeled as ordered categorical variables. Regression estimates reported are all unstandardized probit coefficients. Respondent age, level of education, and family income were controlled in all models by correlating these variables with materialism and religiosity and by predicting financial strain and the retirement outcome variables with them. All information was used in the analyses where data were missing for predictors (equivalent to full information maximum likelihood, using weighted least squares estimation; WLSMV), with the exception that cases with missing data on the outcome variables were dropped from the analyses (this occurred in seven cases).

Married partners' responses to survey research are often correlated or non-independent (Kenny 1996; Kenny et al. 2006). In addition, researchers with data from both partners on the same variables are often interested in both "actor" (e.g., wife predictors of wife outcomes) and "partner" (e.g., wife predictors of husband outcomes) associations. Using the Actor Partner Model of Independence (APIM), Kenny et al. (2006) suggested ways to account for nonindependence in the data, as well as to explore actor and partner associations concurrently.

First, a model was estimated to examine factor structures [including factor loadings for each construct (Table 1)] and latent variable correlations (Table 2). Measurement invariance (Vandenberg and Lance 2000) was tested across spouse reports of the latent variables using the DIFFTEST option associated with WLSMV in MPlus. This allowed us to compare how the measure of constructs was similar or different for husbands and wives. When factor loadings were constrained to be equal across gender, model fit worsened significantly suggesting no measurement invariance $\left(\chi^{2}\right.$ difference $=21.24$, df $=12$, $p=0.047)$. Absolute model fit indices for this model indicated 


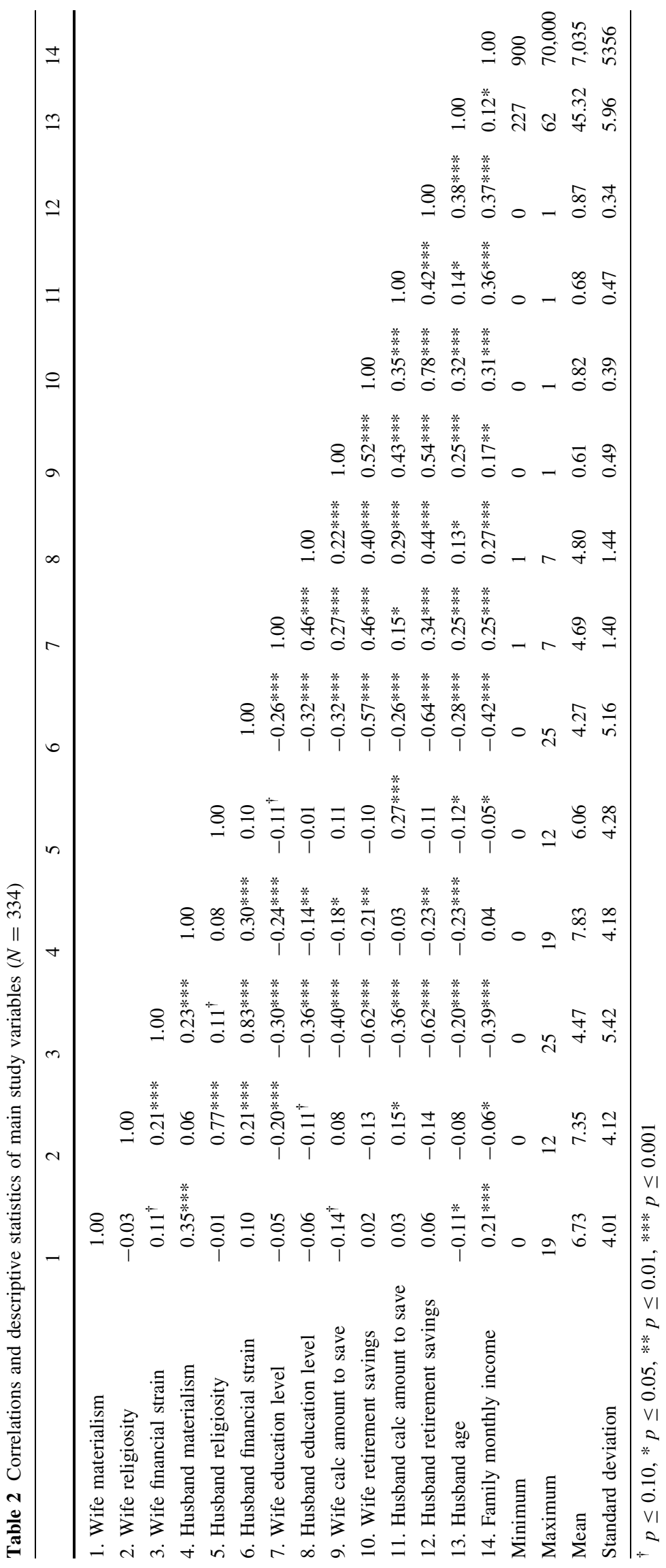


adequate fit to the data $\left[\chi^{2}=849.35, \mathrm{df}=557, p \leq 0.001\right.$; Comparative Fit Index $(\mathrm{CFI})=0.99$; Root Mean Square Error of Approximation (RMSEA) $=0.04]$. Each latent variable in the model demonstrated adequate factor structures (all loadings above 0.49 , with average factor loadings for materialism for females $=0.67$, males $=0.64$; religiosity for females $=0.95$, males $=0.95 ; \quad$ financial strain for females $=0.86$, males $=0.85$ ).

Regarding correlations, wife and husband financial strain were found to be the most highly correlated with other variables in the model. Additionally, all of the husband and wife responses for each latent construct were significantly correlated. The husband and wife materialism measures were modestly correlated $(r=0.35, p<0.001)$. Whether respondents calculated an amount to save for retirement was modestly correlated between husbands and wives $(r=0.43$, $p<0.001)$. The husband and wife religiosity measures $(r=0.77, p<0.001)$, financial strain measures $(r=0.83$, $p<0.001)$, and whether they were saving for retirement $(r=0.78, p<0.001)$ were strongly correlated with their spouse's same measure respectively.

Next, a structural model examined regression paths between the independent variables (materialism and religiosity), the mediating variable (financial strain), and the outcome variables (calculated retirement amount and retirement savings), while controlling for husband's age, husband and wife levels of education, and family income (Fig. 2). Paths in the structural model were constrained to be equal across gender. Specifically, wife actor paths were constrained to be equal to husband actor paths (e.g., the path for wife materialism predicting wife calculated amount to save for retirement was set to equal husband materialism predicting husband calculated amount to save for retirement). Likewise, partner paths were constrained to be equal across gender (e.g., the path for wife materialism predicting husband calculated amount to save for retirement was set to equal husband materialism predicting wife calculated amount to save for retirement). Placing these constraints did not worsen model fit significantly $\left(\chi^{2}\right.$ difference $=19.87, \mathrm{df}=16, p=0.23$ ), and so the final model includes these constraints. Next, the model was run without the eleven income outliers in the sample. When these data were removed from the sample, model fit was still adequate, and significant paths in the model did not change. Model fit indices suggested that the resulting final structural model fit the data adequately $\left(\chi^{2}=889.11\right.$, $\mathrm{df}=580, p \leq 0.001 ; \mathrm{CFI}=0.99$; RMSEA $=0.04)$.

Preacher and Hayes (2008) noted that bootstrapping is the preferred method for calculating correct standard errors when examining multiple mediator models. Bootstrapping is a technique that pulls various random samples from among the analytic sample and pools coefficients across these samples (Preacher and Hayes 2008). However, Nevitt and Hancock
(2001) noted that sample sizes in such analyses must be over 500 for complex models involving non-normally distributed (or categorical) variables. Given model complexity in the current analyses, the non-normal distribution of variables in the model, and the relatively small sample size, bootstrapping to determine adjusted standard errors for the indirect effects was not possible. Indeed when a model involving bootstrapping was estimated, less than half of the bootstrap draws requested were completed, resulting in little confidence that standard errors were correctly estimated. Since bootstrapping could not be used, only indirect effects with $p$ values $\leq 0.01$ are reported as significant to increase confidence in mediation results. Also, Preacher and Hayes (2008) noted that it is valuable to report "combined" indirect effects in multiple mediation models. In other words, it is recommended to report the effect of one predictor on one outcome through multiple mediator variables as a single coefficient. This approach is taken to address our second hypothesis below.

Hypothesis 1: Direct Associations Between Materialism, Religiosity, Financial Strain, and Retirement Preparation Variables

Husband and wife materialism and religiosity had direct links to financial strain and retirement preparation. Specifically, three actor paths were found to be significant. Effects were the same for husbands and wives, as paths were constrained to be equal across spouses. Husbands' and wives' higher materialism was linked with their own higher financial strain $(b=0.32, p \leq 0.001)$. Husbands' and wives' higher religiosity was associated with having determined needs for retirement $(b=0.32, p \leq 0.01)$. Also, husbands' and wives' higher financial strain were related to having stated they had saved for retirement $(b=-0.37$, $p \leq 0.001)$. One partner effect was found to be significant. Husbands' and wives' higher materialism was related to their spouse's higher financial strain $(b=0.16, p \leq 0.05)$.

The amount of the explained variance in financial strain was similar for husbands $\left(R^{2}=0.31\right)$ and wives $\left(R^{2}=0.32\right)$. When looking at whether wives and husbands had calculated an amount to save for retirement, the model explained 27 and $26 \%$ of the variance, respectively. The model explained $49 \%$ of the variance in wife reports of having saved for retirement, and $52 \%$ of the variance in whether husbands stated they had saved for retirement.

Hypothesis 2: Indirect Effects of Materialism and Religiosity on Retirement Preparation Through Financial Strain

There were four significant indirect effects found through a combination of both husbands' and wives' financial strain on the outcome variables. Specifically, wives' materialism was 
Fig. 2 Structural equation model for wife and husband calculation of amount to save for retirement and wife and husband retirement savings predicted by financial strain, materialism, and religiosity. ${ }^{*} p \leq 0.05, * * p \leq 0.01$, $* * * p \leq 0.001$; unstandardized regression coefficients are reported in the figure. $R^{2}$ amount of variance accounted for in endogenous variables. Model fit for this model was: $\chi^{2}=889.11, \mathrm{df}=580$, $p \leq 0.001 ;$ CFI $=0.99$; RMSEA $=0.04$. All husband and wife responses were set to co-vary with each other. Actor and partner effects were constrained to be equal across gender in the final model

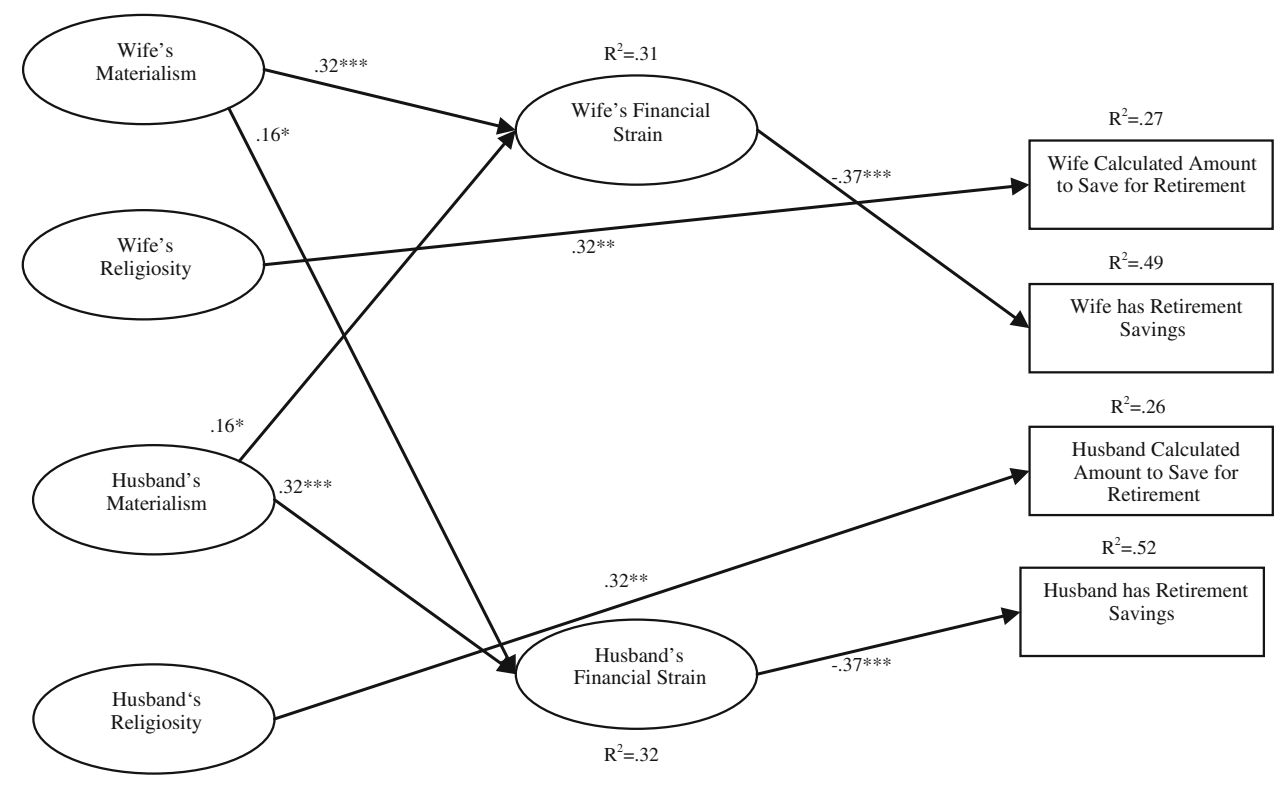

found to indirectly predict, through husband and wife reports of financial strain, whether wives stated they had saved for retirement $(b=-0.15, p \leq 0.001)$. Since actor effects were constrained to be equal, husbands' materialism was also found to indirectly predict, through husband and wife reports of financial strain, whether husbands stated they had saved for retirement $(b=-0.15, p \leq 0.001)$. In addition, wives' materialism was indirectly linked, through financial strain, to whether husbands stated they had saved for retirement $(b=-0.12, p \leq 0.01)$. Again, as partner effects were constrained to be equal, husbands' materialism was also found to indirectly predict, through financial strain, whether wives stated they had saved for retirement $(b=-0.12, p \leq 0.01)$.

Hypothesis 3: Gender Differences Versus Family Socialization Processes in Marriage

Our third hypothesis was evaluated through the use of the Actor Partner Interdependence Model (Kenny et al. 2006). In evaluating gender differences versus socialization (similarities), we expected that if attitudes had not become more similar within marriage, then "actor" and "partner" paths for husbands and wives would be statistically different. Model results indicated that constraining the paths to be equal did not worsen model fit, suggesting that socialization occurred.

\section{Control Variables}

Some of the control variables were predictive of financial strain and retirement preparation (not displayed in Fig. 2), including husbands' higher education level (predicting wife financial strain: $b=-0.18, p \leq 0.001$; predicting husband financial strain: $b=-0.13, p \leq 0.01$ ), husbands' age (predicting wife financial strain: $b=-0.03$, $p \leq 0.001$; predicting husband financial strain: $b=-0.05$, $p \leq 0.001$ ), and the monthly family income (predicting wife financial strain: $b=-0.05, p \leq 0.001$; predicting husband financial strain: $b=-0.06, p \leq 0.001)$. Whether wives had figured out how much they would need to save for retirement, and whether wives stated they had saved for retirement were predicted by wives' education level (calculated amount to save for retirement: $b=0.17, p \leq 0.05$; saved for retirement: $b=0.20, p \leq 0.01$ ), and husbands' age (calculated amount to save for retirement: $b=0.03$, $p \leq 0.01$; saved for retirement: $b=0.04, p \leq 0.01$ ). Monthly family income predicted whether husbands had figured out how much they would need to save for retirement $(b=0.04, p \leq 0.01)$. Also, husbands' education level $(b=0.17, p \leq 0.01)$ and husbands' age $(b=0.05$, $p \leq 0.001)$ predicted whether husbands stated they had saved for retirement.

\section{Discussion}

Using data from 334 married couples, the aim of this study was to examine how materialistic and religious family socialization processes were linked with retirement preparation financial behaviors through financial strain or capability. In partial support of our first hypothesis, husband and wife religiosity reports were related to their own report 
of having considered how much they would need to save for retirement. Also, materialistic attitudes for husbands and wives were linked to both their own and their partners' reports of financial strain. No direct links were found between materialism and financial preparation for retirement. Direct links were supported from husband and wife financial strain to their own reports of having saved for retirement. In partial support of our second hypothesis, indirect links between materialism and having saved for retirement were significant in our model. However, no indirect links were found to be predictive of determining needs for retirement. Regarding our last hypothesis, findings supported the financial socialization in marriage related to retirement preparation, as associations between couple reports were found to be similar.

Direct Associations Between Materialism, Religiosity, Financial Strain, and Retirement Preparation Variables

Materialism was linked to financial strain and, thus, indirectly linked to savings for retirement through financial strain. This finding is in line with Hershey and Mowen's (2000) results which indicated no direct association between materialism and financial preparedness. The current study adds to Hershey and Mowen's findings, as their study did not examine financial strain as an outcome of materialism or as a predictor of financial preparedness. In contrast, materialism was significantly linked to financial strain in the current analysis, as wife and husband materialism predicted their own and partner reports of increased financial strain. Dean et al. (2007) noted a similar trend in their study, with materialism being correlated with increased financial problems. Of note and in support of the current findings, Dean and colleagues suggested stronger "actor" effects than "partner" effects with regard to materialism predicting financial problems. Future research should address the ways that materialism relates to financial strain, including what types of materialism correlate more strongly with financial strain, as well as in what circumstances materialism does or does not predict financial strain.

That materialism was not directly linked to retirement preparation in this study was somewhat surprising. It appears that having materialistic attitudes is not related to having determined how much to save for retirement, and only linked to having saved for retirement through financial strain. Thus, although research has tied materialistic attitudes to saving less for the future, higher spending and debt, and higher financial strain (Dean et al. 2007; Troisi et al. 2006; Watson 2003), it may be that some people with materialistic attitudes also save for retirement when financial strain is not present.
Higher religiosity was directly related to the couples' likelihood of having calculated an amount to save for retirement. This finding is supported by prior research that indicates increased attitudes of thrift among religious individuals (Guiso et al. 2003). Specifically, religious socialization in families may be associated with talking about or making other preparations for future financial needs, such as might be expected with a future-focused financial orientation (Hershey and Mowen 2000; Stawski et al. 2007). That said, religiosity was not linked with either partner's report of financial strain or having saved for retirement. This finding is somewhat in conflict with research by Klaubert (2010) who noted that higher frequency of church attendance was associated with higher savings rates. In summary, religious family socialization processes may be linked to some financial behaviors, such as considering future financial needs, but not to others, such as financial strain and saving for retirement.

Not surprisingly, financial strain was related with whether or not couples had saved for retirement in the current sample. Specifically, wife and husband reports of increased financial strain predicted their own reports of being less likely to have saved for retirement. This is in line with Baek and DeVaney's (2010) findings related to the impact financial strain has on an individual's savings. At a broader level, Blendon and Benson (2009) noted a reduction in confidence among U.S. citizens ( $69 \%$ in $2005,49 \%$ in 2009) in having sufficient income and assets for retirement. Given the importance of financial strain in saving for retirement, additional research is needed to explore financial strain levels among baby boomers. Additional research should also investigate predictors of lower financial strain of those living on fixed incomes such as those living in retirement.

That financial strain was not linked with determining financial needs in retirement is contrary to our hypotheses. One potential explanation for this finding is that people with all levels of financial strain may consider their retirement financial needs. Those with higher strain may act out of concern for the future, while those with low strain may be planning how to use resources.

Indirect Effects of Materialism and Religiosity on Retirement Preparation Through Financial Strain

Although materialism did not have a direct effect on whether either spouse stated they had saved for retirement, both actor and partner indirect effects were found through financial strain. Specifically, wife and husband materialism predicted actor and partner reports of increased financial strain, which were linked to both husband and wife reports of having some retirement savings. This finding supports the notion that financial strain often acts as a mechanism in family financial matters. Most prior studies have examined financial strain as 
being derived from income and as predicting family outcomes such as parent/child relationships, marital relationship quality, and life satisfaction (Lempers and ClarkLempers 1997; Xiao et al. 2009). The current study adds to the literature by drawing on the family socialization of materialistic and religious attitudes, and linking these with retirement preparation through financial strain.

\section{Gender Differences Versus Family Socialization Processes in Marriage}

Findings from the current study suggest that couples in midlife have socialized to each other in terms of how their materialistic and religious attitudes are linked with financial strain and retirement preparation variables. Specifically, when we constrained regression paths from wife predictors to wife outcomes to be equal to those from husband predictors to husband outcomes, model fit essentially did not change. The same was true when regression paths from wife predictors to husband outcomes were constrained to be equal to paths from husband predictors to wife outcomes. Although it is common for male and female experiences around retirement to be different (Dew and Yorgason 2010; Noone et al. 2010), the links between these related variables in this study did not differ across gender. Our study provided an implicit approach to examining family socialization, yet future research could more explicitly test this socialization hypothesis by, for example, comparing newlywed couples with those married longer periods of time, or by comparing single men and single women with married counterparts.

\section{Limitations and Conclusion}

One important limitation in the current study is that the outcome measures of retirement preparation are somewhat rudimentary. Future studies would add to the current findings by including details about retirement preparation and saving such as what type of planning has been done, a projected amount needed for retirement, the actual amount saved for retirement, and the currently monthly or yearly rate of savings.

Another limitation of this study is that many in the sample are somewhat affluent and homogenous. Education and income levels suggest that most are in the middle class, and all participants were married. Granted, the cost of living in the area where the data were collected has a substantially higher cost of living than the average U.S. city. Even so, it is important to further research financial preparation for retirement among more diverse samples including those with fewer resources, such as those with lower incomes or those in single parent families. Further, as the negative results of materialism appear to be directly tied to financial strain, more exploratory work needs to be done to better understand the development of spending attitudes, as well as how these can be influenced to assist with future-oriented thinking.

Despite these limitations, the current study contributes to the literature by examining retirement preparation behaviors among mid-life couples within the context of family socialization. Understanding perspectives from both husbands and wives provides a valuable representation of how financial socialization around retirement issues occurs among couples. Findings support the theoretical framework by demonstrating the influence of family socialization processes on financial socialization outcomes. Additionally, personal characteristics were found to have associations with financial attitudes, knowledge, and capabilities and financial attitudes, knowledge, and capabilities were found to have associations with financial behaviors. Some of the indirect effects identified in the family financial socialization theory were also validated in the current study. Future research needs to continue to evaluate this theory within the context of financial preparation for retirement.

Findings also indicate significant associations between personal characteristics and retirement preparation. Gudmunson and Danes (2011) did not theorize this type of direct association. Further research needs to be done to evaluate the influence personal characteristics and relational interactions may have on financial behaviors directly, as well as indirectly, through financial attitudes, knowledge, and capabilities.

Understanding the links that materialism, religiosity, and financial strain have with determining how much to save for retirement and saving for retirement can inform individuals and couples to better address the changing benefit structures of their employers and take on more responsibility to plan for and save for retirement, thus reducing risk. This study also provides financial counselors with additional areas that may be evaluated when working with couples on their retirement preparation. More specifically, counselors may find value in understanding the socialization of the couple they are working with as this may help in more effectively guiding the couple in achieving their financial retirement goals. Finally, future prospective research linking personal characteristics and relational interactions in mid-life with post-retirement outcomes is needed to better understand the influence socialization may have over the life-course.

\section{References}

Arias, E. (2010). United States life tables, 2006. National Vital Statistics Reports, 58(21), 1-40. Retrieved from http://www.cdc. gov/nchs/data/nvsr/nvsr58/nvsr58_21.pdf. 
Baek, E., \& DeVaney, S. A. (2010). How do families manage their economic hardship? Family Relations, 59, 358-368. doi:10.1111/ j.1741-3729.2010.00608.x.

Belk, R. W. (1985). Materialism: Trait aspects of living in the material world. The Journal of Consumer Research, 12, 265-280. Retrieved from http://www.jstor.org/stable/254373.

Beutler, I. F. (2012). Connections to economic prosperity: Money aspirations from adolescence to emerging adulthood. Journal of Financial Counseling and Planning, 23(1), 17-32. Retrieved from https://www.afcpe.org/assets/pdf/v23_j2.pdf.

Blendon, R., \& Benson, J. (2009). America's response to a deep recession. Challenge, 52(4), 32-52. doi:10.2753/0577-5132520404.

Burgoyne, C. B., Young, B., \& Walker, C. M. (2005). Deciding to give to charity: A focus study in the context of the household economy. Journal of Community and Applied Social Psychology, 15, 383-405. doi:10.1002/casp.832.

Carroll, J. S. (2004). The Comprehensive Marriage Preparation Assessment Survey (COMPASS). Springville, UT: Persona (Copyrighted and patent pending).

Choi, J. J., Laibson, D., Madrian, B. C., \& Metrick, A. (2002). Defined contribution pensions: Plan rules, participant choices, and the path of least resistance. In J. Poterba (Ed.), Tax policy and the economy (Vol. 16, pp. 67-113). Cambridge, MA: MIT Press. Retrieved from http://www.nber.org/chapters/c10863.pdf.

Danes, S. M. (1994). Parental perceptions of children's financial socialization. Journal of Financial Counseling and Planning, 5, 127-149. Retrieved from https://www.afcpe.org/assets/pdf/vol58.pdf.

Dean, L. R., Carroll, J. S., \& Yang, C. (2007). Materialism, perceived financial problems, and marital satisfaction. Family Consumer Science Research Journal, 35(3), 260-281. doi:10.1177/107772 $7 X 06296625$.

Dew, J. P., \& Yorgason, J. B. (2010). Economic pressure and marital conflict in retirement-aged couples. Journal of Family Issues, 31(2), 164-188. doi:10.1177/0192513X09344168.

Ekerdt, D. J., Kosloski, K., \& Deviney, S. (2000). The normative anticipation of retirement by older workers. Research on Aging, 22(1), 3-22. doi:10.1177/0164027500221001.

Employee Benefit Research Institute. (2010). Chapter 10-Aggregate trends in defined benefit and defined contribution retirement plan sponsorship, participation, and vesting (Updated December 2010). Retrieved February 20, 2012, from http://www.ebri. org/pdf/publications/books/databook/DB.Chapter 10.pdf.

Employee Benefit Research Institute. (2011). Chapter 09-Personal savings (updated February 2011) Retrieved February 20, 2012, from http://www.ebri.org/pdf/publications/books/databook/DB. Chapter09.pdf.

Federal Interagency Forum on Aging-Related Statistics. (2008). Older Americans 2008: Key indicators of well-being. Federal Interagency Forum on Aging-Related Statistics. Washington, DC: U.S. Government Printing Office.

Flouri, E. (1999). An integrated model of consumer materialism: Can economic socialization and maternal values predict materialistic attitudes in adolescents? Journal of Socio-Economics, 28(6), 707-724. doi:10.1016/S1053-5357(99)00053-0.

Glass, J. C., \& Kilpatrick, B. B. (1998). Financial planning for retirement: An imperative for baby boomer women. Educational Gerontology, 24(6), 595-617. doi:10.1080/0360127980240606.

Gudmunson, C. G., \& Danes, S. M. (2011). Family financial socialization: Theory and critical review. Journal of Family and Economic Issues, 32(4), 644-667. doi:10.1007/s10834-0119275-y.

Guiso, L., Sapienza, P., \& Zingales, L. (2003). People's opium? Religion and economic attitudes. Journal of Monetary Economics, 50(1), 225-282. doi:10.1016/S0304-3932(02)00202-7.
Hayhoe, C. R., Leach, L. J., Turner, P. R., Bruin, M. J., \& Lawrence, F. C. (2000). Differences in spending habits and credit use of college students. The Journal of Consumer Affairs, 34(1), 113-133. doi:10.1111/j.1745-6606.2000.tb00087.x.

Hershey, D. A., Henkens, K., \& Van Dalen, H. P. (2010). Aging and financial planning for retirement: Interdisciplinary influences viewed through a cross-cultural lens. The International Journal of Aging and Human Development, 70(1), 1-38. doi:10.2190/AG.70.1.a.

Hershey, D. A., \& Jacobs-Lawson, J. M. (2012). Bridging the gap: Anticipated shortfalls in future retirement income. Journal of Family and Economic Issues, 32(3), 306-314. doi:10.1007/s 10834-012-9281-8.

Hershey, D. A., Jacobs-Lawson, J. M., McArdle, J. J., \& Hamagami, F. (2007). Psychological foundations of financial planning for retirement. Journal of Adult Development, 14, 26-36. doi: 10.1007/s10804-007-9028-1.

Hershey, D. A., \& Mowen, J. C. (2000). Psychological determinants of financial preparedness for retirement. The Gerontologist, 40(6), 687-697. doi:10.1093/geront/40.6.687.

Huhmann, B. A., \& McQuitty, S. (2009). A model of consumer financial numeracy. International Journal of Bank Marketing, 27(4), 270-293. doi:10.1108/02652320910968359.

Jacobs-Lawson, J. M., \& Hershey, D. A. (2005). Influence of future time perspective, financial knowledge, and financial risk tolerance on retirement savings behaviors. Financial Services Review, 14(4), 331-344. Retrieved from http://www2.stetson. edu/fsr/abstracts/vol_14_num4_p331.pdf.

Keister, L. A. (2003). Religion and wealth: The role of religious affiliation and participation in early adult asset accumulation. Social Forces, 82(1), 173-205. doi:10.1353/sof.2003.0094.

Kenny, D. A. (1996). Models of non-independence in dyadic research. Journal of Social and Personal Relationships, 13(2), 279-294. doi:10.1177/0265407596132007.

Kenny, D. A., Kashy, D. A., \& Cook, W. L. (2006). Dyadic data analysis. New York: Guilford Press.

Kim, J. E., \& Moen, P. (2002). Retirement transitions, gender, and psychological well-being: A life-course, ecological model. Journal of Gerontology, 57B(3), 212-222. doi:10.1093/geronb/ 57.3.P212.

Klaubert, A. (2010). "Striving for savings"-Religion and individual economic behavior. Working Paper Series in Economics No. 162. University of Lüneburg. Retrieved from http://www. leuphana.de/fileadmin/user_upload/Forschungseinrichtungen/ ifvwl/WorkingPapers/wp_162_Upload.pdf.

Komhauser, M. E. (1994). The morality of money: American attitudes toward wealth and the income tax. Indiana Law Journal, 70, 119-169. Retrieved from http://heinonline.org/HOL/Page? handle=hein.journals/indana70\&div $=12 \& \mathrm{~g} \_$sent $=1 \&$ collection $=$ journals.

Lee, C. (2001). Life-cycle saving in the United States, 1900-90. Review of Income and Wealth, 47(2), 165-179. doi:10.1111/ 1475-4991.00010.

Lempers, J. D., \& Clark-Lempers, D. S. (1997). Economic hardship, family relationships, and adolescent distress: An evaluation of a stress-distress mediation model in mother-daughter and motherson dyads. Adolescence, 32(126), 339-356. Retrieved from http://search.proquest.com/docview/195942921/.

Lewis, C. A., Shevlin, M., McGuckin, C., \& Navrtil, M. (2001). The Santa Clara strength of religious faith questionnaire: Confirmatory factor analysis. Pastoral Psychology, 49, 379-384. doi: 10.1023/A:1010370728546.

Li, J., Montalto, C. P., \& Geistfeld, L. V. (1996). Determinants of financial adequacy for retirement. Financial Counseling and Planning, 7, 39-48. Retrieved from http://www.afcpe.org/assets/ pdf/vol-75.pdf. 
Marks, L. D., Dollahite, D. C., \& Dew, J. P. (2009). Enhancing cultural competence in financial counseling and planning: Understanding why families make religious contributions. Journal of Financial Counseling and Planning, 20(2), 14-26. Retrieved from https://afcpe.org/assets/pdf/vol20_2marks_dollahite_dew.pdf.

Mason, M., Singleton, A., \& Webber, R. (2007). The spirit of generation Y: Young people's spirituality in a changing Australia. Melbourne: John Garrett.

Mock, S. E., \& Cornelius, S. W. (2007). Profiles of interdependence: The retirement planning of married, cohabiting, and lesbian couples. Sex Roles, 56, 793-800. doi:10.1007/s11199-007-9243-z.

Moen, P., Huang, Q., Plassmann, V., \& Detinger, E. (2006). Deciding the future: Do dual-earner couples plan together for retirement? American Behavioral Scientist, 49, 1422-1443. doi:10.1177/ 0002764206286563.

Moen, P., Kim, J. E., \& Hofmeister, H. (2001). Couples' work/ retirement transitions, gender, and marital quality. Social Psychology Quarterly, 64, 55-71. Retrieved from http://www. jstor.org/stable/3090150.

Muthén, L. K., \& Muthén, B. O. (2007). Mplus user's guide (5th ed.). Muthén \& Muthén: Los Angeles, CA.

Neukam, K. A., \& Hershey, D. A. (2003). Financial inhibition, financial activation, and savings for retirement. Financial Services Review, 12(1), 19-37. Retrieved from http://www2. stetson.edu/fsr/abstracts/vol_12_num1_p19.pdf.

Nevitt, J., \& Hancock, G. R. (2001). Performance of bootstrapping approaches to model test statistics and parameter standard error estimation in structural equation modeling. Structural Equation Modeling, 8, 353-377. doi:10.1207/S15328007SEM0803_2.

Noone, J., Stephens, C., \& Alpass, F. (2010). Do men and women differ in their retirement planning? Testing a theoretical model of gendered pathways to retirement preparation. Research on Aging, 32(6), 715-738. doi:10.1177/0164027510383531.

OECD. (2009). Society at a glance 2009: OECD social indicators. OECD Publishing. Retrieved from http://statlinks.oecdcode.org/ 812009011P1G029.xls.

Padilla-Walker, L. M., Harper, J. M., \& Jensen, A. C. (2010). Selfregulation as a mediator between sibling relationship quality and early adolescents' positive and negative outcomes. Journal of Family Psychology, 24(4), 419-428. doi:10.1037/a0020387.

Perkins, K. (1995). Social (in)security: Retirement planning for women. Journal of Women \& Aging, 7(1-2), 37-53. doi: 10.1300/J074v07n01_04.

Petkoska, J., \& Earl, J. K. (2009). Understanding the influence of demographic and psychological variables on retirement planning. Psychology and Aging, 24(1), 245-251. doi:10.1037/a0014096.

Poterba, J., Rauh, J., Venti, S., \& Wise, D. (2007). Defined contribution plans, defined benefit plans, and the accumulation of retirement wealth. Journal of Public Economics, 91, 20622086. doi:10.1016/j.jpubeco.2007.08.004.

Preacher, K. J., \& Hayes, A. F. (2008). Asymptotic and resampling strategies for assessing and comparing indirect effects in multiple mediator models. Behavior Research Methods, 40(3), 879-891. doi:10.3758/BRM.40.3.879.

Rick, S., Small, D. A., \& Finkel, E. (2010). Fatal (fiscal) attraction: Spendthrifts and tightwads in marriage (January 22, 2010). Journal of Marketing Research. http://ssrn.com/abstract=1339240.

Rymarz, R. M., \& Graham, J. (2006). Drifting from the mainstream: The religious identity of Australian core Catholic youth. International Journal of Children's Spirituality, 11(3), 371-383. doi:10.1080/13644360601014114.

Samwick, A. A. (2006). Saving for retirement: Understanding the importance of heterogeneity. Business Economics, 41, 21-27. doi: $10.2145 / 20060103$.

Schulz, A. J., Israel, B. A., Zenk, S. N., Parker, E. A., Lichtenstein, R., Shellman-Weir, S., et al. (2006). Psychosocial stress and social support as mediators of relationships between income, length of residence and depressive symptoms among African American women on Detroit's eastside. Social Science and Medicine, 62, 510-522. doi:10.1016/j.socscimed.2005.06.028.

Skogrand, L., Johnson, A. C., Horrocks, A. M., \& DeFrain, J. (2011). Financial management practices of couples with great marriages. Journal of Family and Economic Issues, 32(1), 27-35. doi: 10.1007/s10834-010-9195-2.

Stafford, M. R., Ganesh, G., \& Luckett, M. G. (1996). Perceived spousal influence in the service decision-making process: A cross cultural investigation. Journal of Applied Business Research, 12(4), 53-69. Retrieved from http://cluteonline. com/journals/index.php/JABR/article/view/5784.

Stawski, R. S., Hershey, D. A., \& Jacobs-Lawson, J. M. (2007). Goal clarity and financial planning activities as determinants of retirement savings contributions. The International Journal of Aging and Human Development, 64(1), 13-32. doi:10.2190/ 13GK-5H72-H324-16P2.

Topa, G., Moriano, J. A., \& Moreno, A. (2012). Psychosocial determinants of financial planning for retirement among immigrants in Europe. Journal of Economic Psychology, 33(3), 527-537. doi: 10.1016/j.joep.2012.01.003.

Troisi, J. D., Christopher, A. N., \& Marek, P. (2006). Materialism and money spending as predictors of economic and personality variables. North American Journal of Psychology, 8(3), 421-436. Retrieved from http://search.proquest.com/docview/ 198087158/.

Vandenberg, R. J., \& Lance, C. E. (2000). A review and synthesis of the measurement invariance literature: Suggestions, practices, and recommendations for organizational research. Organizational Research Methods, 3, 4-70. doi:10.1177/109442810031002.

Walker, C. M. (1996). Financial management, coping and debt in households under financial strain. Journal of Economic Psychology, 17, 789-807. doi:10.1016/S0167-4870(96)00036-0.

Watson, J. J. (2003). The relationship of materialism to spending tendencies, saving, and debt. Journal of Economic Psychology, 24(6), 723-739. doi:10.1016/j.joep.2003.06.001.

Wilska, T. (2002). Me-A consumer? Consumption, identities and lifestyles in today's Finland. Acta Sociologica, 45, 195-210. doi: $10.1177 / 000169930204500302$.

Xiao, J. J., Tang, C., \& Shim, S. (2009). Acting for happiness: Financial behavior and life satisfaction of college students. Social Indicators Research, 92, 53-68. doi:10.1007/s11205-008-9288-6.

\section{Author Biographies}

Scott H. Payne is a doctoral student in Marriage, Family, Human Development at Brigham Young University. His research focus is family financial issues with a special interest in retirement planning. $\mathrm{He}$ is a certified Public Accountant. He received his MS in Marriage and Family Therapy from Brigham Young University.

Jeremy B. Yorgason is an Associate Professor in the School of Family Life at Brigham Young University. His research focus is marital and family issues over the life course. He received his Ph.D. from Virginia Polytechnic Institute and State University. He also was a NIMH Post-doctoral Fellow in Mental Health and Aging at the Pennsylvania State University Gerontology Center.

Jeffrey P. Dew is Assistant Professor of Family, Consumer, and Human Development at Utah State University. His research examines the association between family resources (money and time), the relationship processes surrounding these issues, and relationship quality. He received his Ph.D. at the Pennsylvania State University. 